\title{
ENGLISH COLOUR LEXEMES IN J. K. ROWLING'S NOVELS
}

\author{
Iryna Mykytiuk \\ Yuriy Fedkovych Chernivtsi National University, Chernivtsi, Ukraine \\ i.mykytiuk@chnu.edu.ua \\ Oksana Lesinska \\ Yuriy Fedkovych Chernivtsi National University, Chernivtsi, Ukraine \\ o.lesinska@chnu.edu.ua
}

\begin{abstract}
The article explores lexical units denoting colour in English. The study focuses on colour lexemes in a literary text in terms of their combining potential, structure, and stylistic properties. The undertaken analysis of 11 basic colour lexemes (black, white, grey, red, blue, orange, yellow, green, purple, pink, brown) testifies to their combinability with twelve thematic word-groups that denote: appearance, footgear, dress, headgear, fauna, flora, parts of the body, natural phenomena, objects, magic, substances, food. Sixteen non-basic colour lexemes (sallow, auburn, blank, swarthy, silver, livid, scarlet, gold / golden, blond, amber, emerald, aquamarine, violet, lilac, turquoise, crimson) demonstrate combinability with only five thematic word-groups: appearance, objects, magic, dress, substances. The prevailing usage of the basic colour lexeme black and non-basic colour lexeme gold / golden is explained by the general magical atmosphere created by J. K. Rowling in the novels featuring adventures of the young sorcerer Harry Potter. The analysis of word-building specificity of colour lexemes proves that compounding of the pattern Adj+Adj (white-blond; goldenbrown; light-blue) is the predominant way of their formation. Stylistic devices involving colour lexemes in the analysed literary texts are used with the aim to enhance the expressiveness of the narrative pieces, provide additional characteristics to the people and objects described, produce a humorous effect, and arrange the rhythmical pattern of the utterances. Rowling's choice of certain colour lexemes is illustrative of her individual author's style.
\end{abstract}

Keywords: colour lexeme; thematic group; word-building; stylistic device.

\section{Introduction}

The study of lexical units denoting colour has recently been in the limelight of linguistic research. The diverse nature of this layer of vocabulary stipulates the necessity to analyse it from various viewpoints. Since colour naming may be treated as one of the elements in the semantic structure of a text, scholars investigate characteristics of colour names semantics as well as their stylistic functioning in poetry and prose (Babiy, 2016; Babych, 2013; Vasiutenko, 2012; Kopus', 2015; Tykha, 2014). Functioning of colour lexemes in the structure of phraseological units is elucidated in the works by Semashko (2008), Komanova and Zimovets (2016).

Kul'pina (2002) views linguistics of colour as an "independent scientific paradigm in modern linguistics" (p. 655) and asserts that "linguistics of colour as a scientific research area has clearly defined the object of its scientific study - lexical units comprising colour semes, the object which adequately substantiates the main subject of linguistic research - language and thought, language and society" (p. 655).

Our survey of literature on colour lexemes touches upon only the most influential works, one of which is Berlin and Kay's book Basic Colour Terms: Their Universality and Evolution (1969). In this work, the authors argue against the theory of relativity advanced by Sapir (1921) and Whorf (1956) and formulated by Bloomfield (1933). They advance the idea that unlike physicists, who view the colour-spectrum as a continuous scale of light-waves of different lengths, ranging from 40 to 72 hundred-thousandths of a millimetre, languages mark off different parts of this scale quite arbitrarily and without precise limits, in the meanings of such colour-names as violet, blue, green, yellow, orange, red, and the colour-names of different languages do not embrace the same gradations (p. 140).

Contrary to Bloomfield's views, Berlin and Kay (1969) speak in favour of the theory of universality: “... the referents for the basic colour terms of all languages appear to be drawn from a set of eleven universal perceptual categories, and these categories become encoded in the history of a given language in a particularly fixed order" (p. 4-5).

Claiming that colour is a semantic universal, Berlin and Kay (1969) single out eleven basic colour terms and three psychophysical dimensions of colour terms: hue, brightness and saturation. In a later work, Kay in collaboration with McDaniel (1978) widened the number of basic colour terms to fifteen, distinguishing between six primary basic terms and nine secondary basic terms. Wierzbicka (2008), on her part, considers that there are no "colour universals" in language and thought because many languages "have no word for "colour" (p. 407). According to Wierzbicka (2008), if a language has no word for "colour", it cannot have "a concept of colour" (p. 408), and, consequently, colour universals.

Mykytiuk, I. \& Lesinska, O. (2019). English colour lexemes in J. K. Rowling's novels. Advanced Education, 12, $159-167$. DOI: $10.20535 / 2410-8286.126501$ 
Gibson et al. (2017) trace a connection between the use of colour lexemes and communicative needs of the speakers: "Communicative needs also explain why the number of colour terms varies across languages: Cultures vary in how useful colour is" (p. 10785).

Investigating the system of colour names in the Ukrainian language, Dzivak (1975) suggests that the existing in nature colours should be viewed as a three-dimensional system, since each colour is capable of changing in three directions: hue, saturation, and lightness (p. 25). The author assumes that groups of words characterising one colour form a synonymic row, i.e. a microsystem with a fixed inner structure (p. 27). Dzivak (1975) also claims that the bulk of colour names form the nucleus (white, yellow, green) and the periphery, represented by lexemes denoting colour quality mediately: gun-metal hair, champagne-coloured hair (p. 30).

A number of recent publications approach colour lexemes in terms of their connection with emotions (Hanada, 2018; Takahashi \& Kawabata, 2018). Soriano and Valenzuela (2009) see one of the reasons for this colour-emotion association in "connotative overlap between the colour term and the emotion term" (p. 421). Allan (2009) analyses the connotative power of English colour terms and claims that additional overtones evoked by them are "based upon the visual attributes of the denotatum" (p. 626).

Our approach to the study of colour lexemes is of a practical character and focuses on the analysis of their functioning in the works of fiction.

The objective of the article is to reveal combining capacity, structure, and stylistic characteristics of colour lexemes in a literary text.

\section{Methods}

Prior to our analysis of colour lexemes functioning in a literary text we resorted to Oxford Advanced Learner's Dictionary of Current English (Hornby, 1994), out of which we singled out 11 lexemes that denote basic colour terms and 95 lexemes that denote the hues of basic colour terms, as well as saturation and lightness/brightness.

The results of the analysis of the English language explanatory dictionary were verified on the material of two novels by Joanne K. Rowling: Harry Potter and the Sorcerer's Stone (Rowling, 1998) and Harry Potter and the Chamber of Secrets (Rowling, 1999). In the analysed literary texts the names of colours are represented by 11 basic colour lexemes (297 tokens), 16 non-basic colour lexemes (107 tokens) and 75 derived and compound colour lexemes.

The methods of investigation applied in the paper are the descriptive method (to reveal formal characteristics of colour lexemes); the method of overall selection (to single out colour lexemes necessary for conducting the research); the quantitative method (to establish quantitative characteristics of the analysed units).

\section{Results}

The first step of our analysis is the study of basic colour lexemes in a literary text. Lexeme black is used in attributive function in the fragments describing: appearance: black hair (Rowling, 1998, p. 7); footgear: black shoes (Rowling, 1998, p. 27); dress: black robes (Rowling, 1998, p. 88); headgear: black inside of the hat (Rowling, 1998, p. 97); fauna: black boarhound (Rowling, 1998, p. 111); flora: black trees (Rowling, 1998, p. 200); natural phenomena: low black clouds (Rowling, 1998, p. 138); objects: black chessmen (Rowling, 1998, p. 225). Lexeme black in Rowling's novels helps create a sinister atmosphere that reigns at Hogwarts, the place where the narration unfolds.

Colour lexeme white has been traced in the narrative pieces describing: appearance, complexion in particular, when a person is extremely frightened: white with shock (Rowling, 1998, p. 247), scared white face (Rowling, 1998, p. 116); fauna: white mice (Rowling, 1998, p. 162); parts of the body: white finger (Rowling, 1998, p. 65); objects: snowy white building (Rowling, 1998, p. 56). Though normally associated with light and purity, lexeme white in the analysed text tends to have mainly negative connotations.

Colour lexeme gray portrays: appearance: skin was a dull, granite gray (Rowling, 1998, p. 139); dress: old things gray (Rowling, 1998, p. 24); fauna: gray rat (Rowling, 1998, p. 79); natural phenomena: gray snow (Rowling, 1999, p. 198); substances: gray water (Rowling, 1998, p. 24). Gray in the description of an old, fat rat, Ron's useless possession and a legacy from his brother Percy, emphasises the dullness of the situation when the younger brother is forced to use things (animals included) that once belonged to his elder brothers. Lexeme gray, used to describe evening snow, emphasises dreariness of the winter landscape.

Colour lexeme red is used to represent: appearance: flaming red hair (Rowling, 1998, p. 71); natural phenomena: red sun (Rowling, 1999, p. 31); objects: red ball (Rowling, 1998, p. 133); magic: red sparks (Rowling, 1998, p. 203). Colour red in the description of a personage's face indicates: danger (red in the 
face (Rowling, 1998, p. 15)) - it is Dudley's face that goes red, so there is a danger of his flying into one of his tantrums; extreme embarrassment (go red (Rowling, 1998, p. 63)) - this is what Harry feels when Hagrid mentions 'birthday present'; reaction to alcohol (redder and redder in the face (Rowling, 1998, p. 162)) this is what happens to Hagrid's face as he calls for more wine.

Colour lexeme blue is used to depict: appearance: blue eyes (Rowling, 1999, p. 36); dress: blue sweaters (Rowling, 1998, p. 161); headgear: wig blue (Rowling, 1998, p. 91); natural phenomena: blue sky (Rowling, 1998, p. 211). The sight of the 'bright blue sky' gives Harry a sense of security and confidence as he watches the owl with a note in its mouth fly towards the school.

Colour lexeme orange combines with nouns denoting: appearance: orange eyes (Rowling, 1998, p. 187); dress: orange knickerbockers (Rowling, 1998, p. 24); fauna: orange, fire-dwelling lizard (Rowling, 1999, p. 130); objects: a violent shade of orange: the bedspread, the walls, even the ceiling (Rowling, 1999, p. 40). Orange as a colour is normally associated with warmth and joy, but in Rowling's text, it symbolises violence and fear of the unknown.

Colour lexeme yellow is used to picture: appearance: eyes had turned yellow (Rowling, 1999, p. 225); objects: yellow envelope (Rowling, 1998, p. 26); magical transformations: I tried to turn him yellow (Rowling, 1998, p. 83). In the analysed examples lexeme yellow adds to the creation of a magical atmosphere.

Colour lexeme green is used to specify: appearance: bright green eyes (Rowling, 1998, p. 14); dress: green robes (Rowling, 1999, p. 38); nature: green hills (Rowling, 1998, p. 82); objects: green hangings (Rowling, 1998, p. 247); magical phenomena: green sparks (Rowling, 1998, p. 200); substances: green liquid (Rowling, 1999, p. 79); food: green icing (Rowling, 1998, p. 36). Some usages of lexeme green are positive, especially those associated with life and hope, but green in the analysed text also bears negative connotations: the colour of the cut on Ron's hand - nasty shade of green (Rowling, 1998, p. 190); or the colour of the strange light Harry keeps recollecting in connection with his parents' death - green light (Rowling, 1998, p. 43); or the way Hagrid looked after the underground cart ride - very green (Rowling, 1998, p. 58).

Colour lexeme purple collocates with nouns depicting: appearance: purple face (Rowling, 1998, p. 17); dress: purple cloak (Rowling, 1998, p. 6); headwear: purple turban (Rowling, 1998, p. 97); natural phenomena: purple sky (Rowling, 1998, p. 88); objects: purple cushion (Rowling, 1998, p. 64); magical phenomena: purple firecrackers (Rowling, 1998, p. 137). Purple colour is associated with dignity and grandeur in the description of Albus Dumbledore. At the same time, in the description of Uncle Vernon 'purple face' testifies to nothing other than his extreme anger.

Colour lexeme pink serves to describe: appearance: pink face (Rowling, 1998, p. 15); dress: pink silk dress (Rowling, 1998, p. 104); flora: pink flowers (Rowling, 1999, p. 235); objects: pink umbrella (Rowling, 1998, p. 49). Lexeme pink represents sweetness and charm, but also embarrassment, for example, that of Mrs. Weasley: cheeks rather pink (Rowling, 1999, p. 36), or that of Draco Malfoy: pink tinge (Rowling, 1998, p. 86).

Colour lexeme brown is used to specify: appearance: brown hair (Rowling, 1998, p. 83); fauna: brown chickens (Rowling, 1999, p. 32); objects: brown envelope (Rowling, 1998, p. 25). Brown in the analysed text helps to create the image of reliable and trustworthy Hermione: eyes ... brown (Rowling, 1999, p. 228), bushy brown hair (Rowling, 1999, p. 55).

Thus, basic colour lexemes help portray the images of literary personages and reveal insights into the idea of the literary work under discussion.

The use of basic colour lexemes with different thematic groups of words is reflected in Table 1.

As we may judge from the table, all eleven basic colour lexemes are used in the analysed novels to describe appearance. Nine colour lexemes (black, white, red, orange, yellow, green, purple, pink, brown) characterise objects. Seven colour lexemes (black, gray, blue, orange, green, purple, pink) are used to describe a dress. Natural phenomena are portrayed with the help of six basic colour lexemes: black, gray, red, blue, green, purple. Five colour lexemes (black, white, gray, orange, brown) are used to present fauna. Magic is described with the help of four lexemes: red, yellow, green and purple, while headgear - by three colour lexemes: black, blue and purple. Two colour lexemes (black and pink) depict flora; the same number of lexemes, though different ones (gray and green) describe substances. Footgear is characterised only by the lexeme black, parts of the body - by white, food - by the lexeme green. The results above also prove that a basic colour lexeme black combines with most thematic groups, namely appearance, footgear, dress, headgear, fauna, flora, natural phenomena, and objects. 
Table 1.Combinability of basic colour lexemes with thematic groupings

\begin{tabular}{|c|c|c|c|c|c|c|c|c|c|c|c|}
\hline & $\frac{\frac{y}{0}}{\frac{\pi}{m}}$ & $\frac{\stackrel{0}{\exists}}{\sum_{3}^{3}}$ & $\vec{心}$ & $\underset{\mathscr{D}}{\mathscr{D}}$ & $\stackrel{\mathscr{g}}{\mathscr{m}}$ & 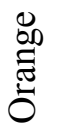 & $\frac{3}{0}$ & $\begin{array}{l}\bar{D} \\
\stackrel{D}{0}\end{array}$ & $\frac{\stackrel{0}{2}}{2}$ & $\stackrel{\mathscr{a}}{\Xi}$ & م \\
\hline Appearance & + & + & + & + & + & + & + & + & + & + & + \\
\hline Footgear & + & - & - & - & - & - & - & - & - & - & - \\
\hline Dress & + & - & + & - & + & + & - & + & + & + & - \\
\hline Headgear & + & - & - & - & + & - & - & - & + & - & - \\
\hline Fauna & + & + & + & - & - & + & - & - & - & - & + \\
\hline Flora & + & - & - & - & - & - & - & - & - & + & - \\
\hline Parts of the body & - & + & - & - & - & - & - & - & - & - & - \\
\hline Natural phenomena & + & - & + & + & + & - & - & + & + & - & - \\
\hline Objects & + & + & - & + & - & + & + & + & + & + & + \\
\hline Magic & - & - & - & + & - & - & + & + & + & - & - \\
\hline Substances & - & - & + & - & - & - & - & + & - & - & - \\
\hline Food & - & - & - & - & - & - & - & + & - & - & - \\
\hline
\end{tabular}

Quantitative analysis of the frequency of 11 basic colour lexemes (297 tokens - 100\%) in a literary text proves that the lexeme black is predominantly used in the analysed novels ( 83 tokens $-27,9 \%$ ). The following in frequency is the lexeme green (40 tokens - 13,5\%). The use of colour lexemes white and red is nearly identical - $37(12,5 \%)$ and $35(11,7 \%)$ tokens respectively. A basic colour lexeme gray is used 22 times $(7,4 \%)$, a colour lexeme blue -19 times $(6,4 \%)$, pink -18 times $(6,1 \%)$, a colour lexeme purple -17 times $(5,7 \%)$, brown -11 times $(3,7 \%)$, while a colour lexeme yellow -8 times $(2,7 \%)$. A colour lexeme orange is used least often -7 tokens, constituting $2,4 \%$ of all analysed basic colour lexemes.

Our next step is the analysis of non-basic colour lexemes in a literary text. In the description of Professor Quirrell along with the basic colour lexeme black, which describes his hair, a non-basic colour lexeme sallow, which portrays his appearance, is used: "Professor Quirrell, in his absurd turban, was talking to a teacher with greasy black hair, a hooked nose, and sallow skin" (Rowling, 1998, p. 100).

Another non-basic colour lexeme auburn serves to characterise the colour of wizard Dumbledore's hair: "They didn't see another person until they reached the entrance hall, when a tall wizard with long, sweeping auburn hair and a beard called to Riddle from the marble staircase" (Rowling, 1999, p. 245).

The description of the shades of the characters' complexion blank and swarthy may be traced in the following examples: "The white queen turned her blank face toward him" (Rowling, 1998, p. 227); "He had a swarthy, clever face” (Rowling, 1998, p. 56).

Non-basic colour lexeme silver is used to provide additional characteristics, in particular to appearance: blushing silver (Rowling, 1999, p. 326); objects: silver lettering (Rowling, 1999, p. 127); magical phenomena: silver writing (Rowling, 1999, p. 127).

The scar on Harry's forehead is perceived more vividly due to the use of non-basic colour lexeme livid: "He looked carefully at Harry, his eyes lingering on the scar that stood out, livid, on Harry's forehead" (Rowling, 1998, p. 205). The lexeme livid also describes Ron's reaction to 'a point some ten feet above the forest floor': livid with terror (Rowling, 1999, p. 275).

Non-basic colour lexeme scarlet is used in the fragments presenting: appearance: scarlet in the face (Rowling, 1999, p. 85); objects: scarlet steam engine (Rowling, 1998, p. 73); dress: scarlet Quidditch robes (Rowling, 1998, p. 147); magical phenomena: scarlet light (Rowling, 1999, p. 190); substances: scarlet ink (Rowling, 1999, p. 39). Non-basic colour lexeme gold / golden combines with the nouns denoting: appearance: golden hair (Rowling, 1999, p. 89); dress: uniform of scarlet and gold (Rowling, 1998, p. 56); objects: golden ribbon (Rowling, 1998, p. 102); magical creatures: golden tail, golden talons (Rowling, 1999, p. 315). Non-basic colour lexeme blond characterises appearance: blond boy (Rowling, 1998, p. 13). Non-basic colour lexeme amber describes substances: amber liquid (Rowling, 1998, p. 36). Non-basic colour lexeme emerald describes appearance, while lexeme aquamarine - dress: emerald eyes (Rowling, 1999, p. 305); robes of aquamarine (Rowling, 1999, p. 77). Non-basic colour lexeme violet characterises 
dress: violet cloak (Rowling, 1998, p. 3); magical phenomena: violet light (Rowling, 1998, p. 45). Non-basic colour lexeme lilac is used for the description of magical phenomena: lilac blot (Rowling, 1999, p. 120); dress: Robes, jade-green, lilac (Rowling, 1999, p. 296). Non-basic colour lexeme turquoise is used to portray: dress: turquoise robes (Rowling, 1999, p. 98); objects: turquoise car (Rowling, 1999, p. 24). Nonbasic colour lexeme crimson is used to depict: appearance: crimson forehead (Rowling, 1999, p. 88); magical creatures: crimson bird (Rowling, 1999, p. 315). Each particular instance of usage of a non-basic colour lexeme is demonstrative in terms of reflecting the speaker's emotional state. Collectively and discretely non-basic colour lexemes serve to reflect Rowling's individual style and manner of poetic presentation of imaginary reality.

The use of non-basic colour lexemes within different thematic groups of words is reflected in Table 2.

Table 2. Combinability of non-basic colour lexemes with thematic groupings

\begin{tabular}{|c|c|c|c|c|c|c|c|c|c|c|c|c|c|c|c|c|}
\hline & $\frac{3}{0}$ & 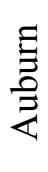 & $\frac{\underline{\vec{J}}}{\bar{m}}$ & 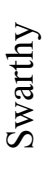 & $\frac{\dot{\bar{D}}}{\bar{\Delta}}$ & . & 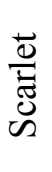 & $\frac{\nabla}{\circlearrowright}$ & $\frac{\vec{\sigma}}{\overline{0}}$ & 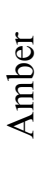 & 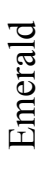 & 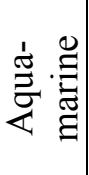 & $\begin{array}{l}\frac{\overrightarrow{0}}{0} \\
\stackrel{\rho}{>}\end{array}$ & $\frac{\mathbb{E}}{=}$ & 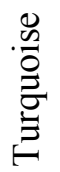 & 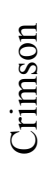 \\
\hline Appearance & + & + & + & + & + & + & + & + & + & - & + & - & - & - & - & + \\
\hline Objects & - & - & - & - & + & - & + & + & - & - & - & - & - & - & + & - \\
\hline Magic & - & - & - & - & + & - & + & + & - & - & - & - & + & + & - & + \\
\hline Dress & - & - & - & - & - & - & + & + & - & - & - & + & + & + & + & - \\
\hline Substances & - & - & - & - & - & - & + & - & - & + & - & - & - & - & - & - \\
\hline
\end{tabular}

The table illustrates the combinability of 16 non-basic colour lexemes with 5 thematic groups of words in the literary text under analysis. As we may see, 11 non-basic colour lexemes (sallow, auburn, blank, swarthy, silver, livid, scarlet, gold / golden, blond, emerald, crimson) combine with nouns denoting appearance. Lexical units connected with magical phenomena are combined with 6 non-basic colour lexemes (silver, scarlet, gold / golden, violet, lilac, crimson). Words denoting items of dress are combined with the same number of non-basic colour lexemes (scarlet, gold / golden, aquamarine, violet, lilac, turquoise). Four non-basic colour lexemes (silver, scarlet, gold / golden, turquoise) combine with nouns denoting objects. Two non-basic colour lexemes (scarlet, amber) also combine with nouns denoting substances. At the same time, units of all 5 thematic groups of words can be combined with non-basic colour lexeme scarlet.

The undertaken quantitative analysis of non-basic colour lexemes frequency $(107$ tokens $-100 \%)$ in a literary text proves that the lexeme gold / golden is used in the analysed novels most often (30 tokens $28,1 \%)$. Next in frequency is the lexeme silver (28 tokens - 26,2\%). Non-basic colour lexeme scarlet is used 19 times $(17,8 \%)$, the lexeme emerald -8 times $(7,5 \%)$. Other non-basic colour lexemes are employed in the text not so frequently: turquoise -5 tokens $(4,7 \%)$; violet and lilac -3 tokens each (2,8\% respectively); sallow and crimson -2 tokens each (1,9\% respectively); auburn, blank, swarthy, livid, blond, amber, aquamarine -1 tokens each ( $0,9 \%$ respectively).

Word-building processes in the analysed colour lexemes may be illustrated by the following examples: simple words: a pair that wasn't pink (Rowling, 1999, p. 92); derived words: fell into blackness (Rowling, 1998, p. 238); faint pinkish glow (Rowling, 1999, p. 31); reddening slightly (Rowling, 1999, p. 244).

In the examples above colour lexemes are formed according to the following word-building patterns: adjective + suffix -ness $\rightarrow$ noun: black $\rightarrow$ blackness; adjective + suffix -ish $\rightarrow$ adjective: pink $\rightarrow$ pinkish; adjective + suffix $-e n \rightarrow$ verb: $r e d \rightarrow$ redden.

Compound colour lexemes are built by way of combining such stems as:

(1) noun-stem + adjective stem ( $\mathrm{N}+\mathrm{Adj})$, e.g.: rolling up his jade-green sleeves (Rowling, 1999, p. 173) - compound colour lexeme jade-green is formed on the basis of similarity to minerals; he carried $a$ lime-green bowler (Rowling, 1999, p. 261) - lime-green is formed on the basis of similarity to fruit; $a$ canary-yellow circus tent (Rowling, 1998, p. 50) - compound colour lexeme canary-yellow is formed on the basis of similarity to birds;

(2) adjective stem + adjective stem (Adj+Adj), e.g.: he had white-blond hair (Rowling, 1998, p. 205); the golden-brown bean (Rowling, 1998, p. 242); twinkling light-blue gaze (Rowling, 1999, p. 144). In these compounds, one lexeme is a basic colour term, while the other - a non-basic one;

(3) adjective stem + noun-stem + suffix -ed (Adj+N+ed), e.g.: that black-haired boy (Rowling, 1998, p. 76); pink-faced girl with blonde pigtails (Rowling, 1998, p. 95) - given compound adjectives usually characterise the personages' hair and face; 
(4) adjective stem + and + adjective stem (Adj+and+Adj), e.g.: black-and-white Lockhart (Rowling, 1999, p. 106); a large black-and-gold cabinet (Rowling, 1999, p. 129); the pink-and-gold sky (Rowling, 1999, p. 105). These compound adjectives give additional characteristics to people, objects, and natural phenomena.

Compound words, built according to the pattern Adj+Adj, are used in the analysed literary texts most frequently - 22 tokens $(29,4 \%)$. Compound words of the pattern Adj+N+ed are employed 21 times (28\%), while compound words of the pattern N+Adj - 19 times (25,3\%). Eight tokens of derived colour lexemes make up $10,7 \%$ of all analysed word-building means. Compound words of the pattern Adj+and+Adj are represented only by 5 examples $(6,6 \%)$.

We now come to the analysis of stylistic devices that involve the usage of colour lexemes. Basic colour lexeme black is used in the stylistic device of simile thus making the description of the giant more expressive: "His face was almost completely hidden by a long, shaggy mane of hair and a wild, tangled beard, but you could make out his eyes, glinting like black beetles under all the hair" (Rowling, 1998, p. 35).

Striking example of simile (with basic colour lexeme blue) in the following example makes the description of the centaur more vivid: "He had astonishingly blue eyes, like pale sapphires" (Rowling, 1998, p. 205).

Expressive simile in the sentence given below helps the reader perceive Ron's feelings at the sight of his father's car: "As Ron walked, open-mouthed, toward it, it moved slowly toward him, exactly like a large, turquoise dog greeting its owner" (Rowling, 1999, p. 274).

Another simile involving a basic colour lexeme gray serves to create humorous effect in the novel: it describes the dirty state of Harry's wand after the latter has been pulled out of the troll's nose: "It was covered in what looked like lumpy gray glue" (Rowling, 1998, p. 141). Basic colour lexeme red and nonbasic colour lexeme gold are used in the simile describing Harry's experience with one of the wands which Mr. Ollivander offered him: "He raised the wand above his head, brought it swishing down through the dusty air and a stream of red and gold sparks shot from the end like a firework, throwing dancing spots of light on to the walls" (Rowling, 1998, p. 66). Humorous effect is also created by the simile describing the change of Uncle Vernon's face colour when he is reading the letter addressed to Harry (basic colour lexemes red and green): "His face went from red to green faster than a set of traffic lights" (Rowling, 1998, p. 26). Ernie's manipulations with Nearly Headless Nick look funnier due to such simile (basic colour lexeme black): "This Ernie did, fanning Nick along like a silent black hovercraft" (Rowling, 1999, p. 204). The general magical atmosphere of the novel allows for a stunning simile (basic colour lexeme green): "His eyes are as green as a fresh pickled toad" (Rowling, 1999, p. 240). Association of ghost's appearance with white colour serves as a ground for such simile (basic colour lexeme white): "Lockhart was getting to his feet a little ways away, covered in slime and white as a ghost" (Rowling, 1999, p. 302). Ron's complexion is compared to flowers in the following example (basic colour lexeme pink): "Ron went as brightly pink as Lockhart's valentine flowers and closed his mouth again" (Rowling, 1999, p. 331). Imaginative comparison of the Hogwarts train to a reptile gives rise to such simile (non-basic colour lexeme scarlet): "The Hogwarts Express was streaking along below them like a scarlet snake" (Rowling, 1999, p. 71).

Metaphor is another stylistic device which adds expressiveness to the narration. Basic colour lexeme black (two adjectives and a derived noun blackness) is used in sentences containing metaphors: "A few embers were still glowing in the fireplace, turning all the armchairs into hunched black shadows" (Rowling, 1998, p. 123); "A thousand live bats fluttered from the walls and ceiling while a thousand more swooped over the tables in low black clouds" (Rowling, 1998, p. 137); "Stars were blossoming in the blackness" (Rowling, 1999, p. 73). Hermione's sorcery is described with the help of the metaphor having a basic colour lexeme blue: "Bright blue flames shot from her wand onto the hem of Snape's robes" (Rowling, 1998, p. 152).

Metaphor in the following sentence emphasises the creepiness of the landscape (basic colour lexeme blue and non-basic colour lexeme silver): "Every now and then a ray of moonlight through the branches above lit a spot of silver-blue blood on the fallen leaves" (Rowling, 1998, p. 200-201). Another metaphor enhances the beauty of the sky as the old Ford Anglia floats through the clouds (basic colour lexemes blue and white): "The wheels of the car skimmed the sea of fluffy cloud, the sky a bright, endless blue under the blinding white sun" (Rowling, 1999, p. 71).

Metaphor in the example below makes the funny scene of Ron's having trouble with his wand still funnier (basic colour lexeme purple): “... Ron was having trouble with his wand again; large purple bubbles were blossoming out of the end, and he wasn't much interested in anything else" (Rowling, 1999, p. 239). Striking metaphorical description of rain may be traced in the following example (non-basic colour lexeme 
silver): “... he began a kind of roller-coaster ride around the edges of the stadium, squinting through the silver sheets of rain to the Gryffindor goal posts ..." (Rowling, 1999, p. 170-171).

Trite metaphor is used in the description of Albus Dumbledore, but the unusual combination of words makes the sentence expressive (non-basic colour lexeme silver): "He was tall, thin, and very old, judging by the silver of his hair and beard, which were both long enough to tuck into his belt" (Rowling, 1998, p. 6).

A variety of metaphor - personification - is used in the following example (non-basic colour lexemes silver and gold): "Cups, shields, plates, and statues winked silver and gold in the darkness" (Rowling, 1998, p. 125).

By adding forget-me-not to the word combination blue sky the author creates an expressive epithet that makes the reader perceive actual resemblance of the sky to the flower: "The sky was a clear, forget-me-not blue, and there was a feeling in the air of summer coming" (Rowling, 1998, p. 183). Epithet in the following example gives additional characteristics to the hero's appearance (basic colour lexeme black): “... Hagrid, the Hogwarts gamekeeper, came striding toward them, beetle-black eyes flashing over his great bristling beard" (Rowling, 1999, p. 54).

Non-basic colour lexeme silver serves as a means of creating an image-bearing epithet as in the example: “... she said, silver tears welling rapidly in her small, see-through eyes" (Rowling, 1999, p. 134). Epithet white-hot in the following example serves the purpose of figurative representation of unbearable pain which ran through Harry: "White-hot pain was spreading slowly and steadily from the wound" (Rowling, 1999, p. 320).

Expressiveness of the description is achieved due to the use of comparative epithets as in the following example (basic colour lexeme yellow): "He looked down and found himself gazing into a pair of lamp-like yellow eyes" (Rowling, 1999, p. 124).

Basic colour lexeme black is used in the stylistic device of metonymy, where it helps build up imagery:

"Through the forest of pointed black Hogwarts hats, Harry saw a long line of scared-looking first years filing into the Hall" (Rowling, 1999, p. 76).

Humorous effect is also produced by zeugma, a stylistic device that involves syntactic similarity but semantic heterogeneity: “wearing a pink bathrobe and a frown” (Rowling, 1998, p. 123).

Phonetic stylistic devices, in particular alliteration, creates a rhythmic effect of the utterance: "Dudley was blond, pink, and porky" (Rowling, 1999, p. 4); "A patch of scarlet swam past, and Harry heard a soft clatter of claws beside him” (Rowling, 1999, p. 320).

\section{Discussion and Conclusions}

Our findings prove that 11 basic colour lexemes (black, white, grey, red, blue, orange, yellow, green, purple, pink, brown) (297 tokens) combine with 12 groups of words denoting: appearance, footgear, dress, headgear, fauna, flora, parts of the body, natural phenomena, objects, magic, substances, food. We have also discovered that all basic colour lexemes are used in text fragments describing appearance of the characters (black hair; white with shock; gray-faced; red in the face; blue eyes; orange eyes; eyes had turned yellow; look very green; purple in the face; cheeks rather pink; brown hair). Interestingly, lexeme black has proved to be used in the analysed fictional texts most frequently occurring in text fragments depicting appearance (black hair), footgear (black shoes), dress (black robes), headgear (black hat), fauna (black boarhound), flora (black trees), natural phenomena (low black clouds), and objects (black chessmen).

Sixteen non-basic colour lexemes (sallow, auburn, blank, swarthy, silver, livid, scarlet, gold / golden, blond, amber, emerald, aquamarine, violet, lilac, turquoise, crimson) (107 tokens) combine with a smaller number of thematic groups: appearance, objects, magic, dress, substances. Eleven non-basic colour lexemes out of the analysed 16 are used to describe appearance (sallow skin; auburn hair; blank face; swarthy face; blushing silver; livid scar; scarlet in the face; golden hair; blond boy; emerald eyes; crimson forehead). The only non-basic colour lexeme that combines with all thematic groups is the word scarlet (scarlet in the face; scarlet steam engine; scarlet Quidditch robes; scarlet light; scarlet ink), but the most frequently used nonbasic colour lexeme is gold / golden.

The magical atmosphere created by J. K. Rowling in the novels about adventures of the young sorcerer Harry Potter in Hogwarts School of Witchcraft and Wizardry may well serve as an explanation for the prevailing use of lexemes commonly associated with magic, i.e. the basic colour lexeme black and the nonbasic colour lexeme gold / golden.

The analysis of word-building characteristics of colour lexemes was carried out on the material of 75 derived and compound lexemes. Compound colour lexemes of the pattern Adj+Adj (white-blond; goldenbrown; light-blue) have proved to be used in the literary text most often. 
Our results are consistent with other studies which have shown that the choice of colour represents one of the forms of the author's projection of the surrounding reality (Babych, 2013, p. 183); that colour serves to reproduce a multitude of the author's emotions (Kopus', 2015, p. 89); the author's artistic mind is aimed at visual reflection of reality (Vasiutenko, 2012, p. 7); the author perceives the world through colour and tends to express emotions, feelings and impressions "in 'colour' associations" (Tykha, 2014, p. 260).

We extend these views by suggesting that apart from serving as markers of Rowling's individual style, basic and non-basic colour lexemes in her texts serve to portray the images of the personages by reflecting their emotional states and feelings.

We agree with Babiy (2016) who came to conclusions that colour names are a significant constituent of a literary text imagery (p.94), but imaginary also involves figurative language. We have analysed colour lexemes as the components of stylistic devices at different language levels and traced similes, metaphors, personifications, epithets, metonymies, zeugmas, as well as a phonetic stylistic device of alliteration. We have also revealed the functions of stylistic devices involving colour lexemes in the analysed literary texts. They serve to add expressiveness to the narration, give additional characteristics to the objects described, organise the rhythmical pattern of the utterance, and create a humorous effect.

Vasiutenko (2012) claims that each author has a favourite colour which is prevalent in his/her creative work (p. 4). Rowling seems to favour not only a certain colour but a certain literary character as well. In terms of colour characterisation Ron Weasley is given precedence over other personages. Emotions reflected on his face are those of: embarrassment (ears went pink; turning a bit pink; scarlet in the face; crimson forehead); annoyance (face as red as his hair); anger (red as Ron's ears); extreme pleasure (purple in the face; went as brightly pin); fear for himself (white-faced); fear for Harry (gray-faced).

The obtained qualitative and quantitative data call for further research in contrastive English Ukrainian aspect. We wonder if we could contribute in some way to "colour universals in language and thought' discussion by conducting a comprehensive analysis of colour lexemes functioning in the novels by contemporary Ukrainian writer G. Pahutiak, who works in the same literary genre as Rowling does.

\section{References:}

Allan, K. (2009). The connotations of English colour terms: colour-based X-phemisms. Journal of Pragmatics, 41 (3), $626-637$. https://doi.org/10.1016/j.pragma.2008.06.004

Babiy, I. (2016). Manifestatsiya obrazno-symvolichnykh uzhyvan' nazv kol'oriv u khudozhniy prozoviy movi [Manifestation of image-bearing and symbolic usages of colour names in literary prose language]. Naukovi Zapysky Natsional'noho universytetu "Ostroz'ka Akademia", 60, 91-94. Retrieved November 2, 2017, from http://nbuv.gov.ua/UJRN/Nznuoaf_2016_60_37

Babych, T. (2013). Semantyka kol'oratyviv u poetychnykh tekstakh L. V. Kostenko [Semantics of colour names in L. V. Kostenko's poetic texts]. Movoznavchyi Visnyk, 16/17, 182-188. Retrieved November 2, 2017, from http://biblioteka.cdu.edu.ua/bulleten/movozn_visnuk_16_17.pdf

Berlin, B., \& Kay, P. (1969). Basic Colour Terms: Their Universality and Evolution. Berkeley \& Los Angeles: University of California Press.

Bloomfield, L. (1933). Language. London: George Allen \& Unwin Ltd.

Dzivak, O. (1975). Pro systemu nazv kol'oriv u suchasniy ukrayins'kiy literaturniy movi [On the system of names of colours in modern Ukrainian literary language]. Ukrainske movoznavstvo, 3, 25-31. Retrieved November 3, 2017, from http://philology.knu.ua/files/library/ukrmov/\%D3\%CC_\%203.pdf

Gibson, E. et al. (2017). Color naming across languages reflects color use. PNAS, 114 (40), 10785-10790. https://doi.org/10.1073/pnas.1619666114

Hanada, M. (2018). Correspondence analysis of color-emotion associations. Color Research and Application, 43 (2), $224-237$. https://doi.org/10.1002/col.22171

Hornby, A. S. (1994). Oxford Advanced Learner's Dictionary of Current English. Oxford: Oxford University Press.

Kay, P., \& McDaniel, Ch. K. (1978). The Linguistic Significance of the Meanings of Basic Colour Terms. Language, 54 (3), 610 646. Retrieved October 15, 2017, from http://www1.icsi.berkeley.edu/ kay/K\&McD.LG.pdf

Komanova, A. \& Zimovets, N. (2016). Frazeologizmy s elementami tsvetooboznacheniy (na primere angloyazychnoy pressy) [Phraseological units with elements of colour names (case study of the English press)]. Filologicheskiye nauki. Voprosy teorii i praktiki, 6 (60), 120-124. Retrieved December 12, 2017, from www.gramota.net/materials/2/2016/6-1/35.html

Kopus', O. (2015). Semantyka leksem zi znachenniam kol'oru v romani Larysy Denysenko 'Vid zahybloho dida do pomerloho. Vidlunnia [Semantics of lexemes with the meaning 'colour' in the novel by Larysa Denysenko 'From the grandfather killed in battle to the grandfather dead. Echo]. Ridnyi krai, 1 (32), 83-89. Retrieved November 3, 2017, from http://dspace.pnpu.edu.ua/handle/123456789/5901

Kul'pina, V. (2002). Teoreticheskie aspekty lingvistiki tsveta kak nauchnogo napravleniya sopostavitel'nogo yazykoznaniya [Theoretical aspects of colour linguistics as a scientific field of contrastive linguistics]. Moscow, Russia: M. V. Lomonosov Moscow State University. Retrieved November 3, 2017, from http://www.dissercat.com/content/teoreticheskie-aspektylingvistiki-tsveta-kak-nauchnogo-napravleniya-sopostavitelnogo-yazyko

Rowling, J. K. (1998). Harry Potter and the Sorcerer's Stone. New York: Scholastic Press.

Rowling, J. K. (1999). Harry Potter and the Chamber of Secrets. New York: Scholastic Press.

Sapir, E. (1921). Language. An Introduction to the study of speech. New York: Harcourt, Brace \& World. 
Semashko, T. (2008). Osoblyvosti semantyky ta funktsionuvannia sliv-koloratyviv $v$ ukrayins'kiy frazeolohiyi [Peculiarities of semantics and functioning of words denoting colour in Ukrainian phraseology]. Extended abstract of Cand. Sci. Dissertation, M. P. Drahomanov National Pedagogical University, Kyiv, Ukraine. Retrieved November 4, 2017, from http://www.enpuir.npu.edu.ua/bitstream/123456789/501/3/Semashko.pdf

Soriano, C. \& Valenzuela, J. (2009). Emotion and colour across languages: implicit associations in Spanish colour terms. Social Science Information, 48 (3), 421-445. https://doi.org/10.1177/0539018409106199

Takahashi, F. \& Kawabata, Ya. (2018). The association between colors and emotions for emotional words and facial expressions. Color Research and Application, 43 (2), 247-257. https://doi.org/10.1002/col.22186

Tykha, L. (2014). Semantyka kol'oru u poetychnykh tekstakh Vasylya Holoborod'ka [Semantics of colour in poetic texts by Vasyl' Holoborod'ko]. Typolohiya ta funktsiyi movnykh odynyts', 2, 255-261. Retrieved October 18, 2017, from http://esnuir.eenu.edu.ua/handle/123456789/4744

Vasiutenko, I. (2012). Semantyka i funktsionuvannia kol'oronazv yak zasib khudozhn'oho vidobrazhennia u poetychniy movotvorchosti Mykoly Bazhana [Semantics and functioning of colour names as a means of artistic portrayal in poetic language creativity of Mykola Bazhan]. Linhvistychni doslidzhennia, 33, 3-7. Retrieved November 4, 2017, from http://nbuv.gov.ua/UJRN/znpkhnpu_lingv_2012_33_3

Whorf, B. L. (1956). Language, Thought, and Reality. Selected writings. Cambridge: Technology Press of Massachusetts Institute of Technology.

Wierzbicka, A. (2008). Why there are no 'colour universals' in language and thought. Journal of the Royal Anthropological Institute, 14 (2), 407-425. https://doi.org/10.1111/j.1467-9655.2008.00509.x

Received: March 21, 2018

Accepted: May 02, 2019 